\title{
INTER-STATION CORRELATIONS OF OZONE CONCENTRATIONS \\ IN THE SAN FRANCISCO BAY AREA
}

CLIFFORD HAYASHI ${ }^{1}$

Stanford University

\section{MASTER}

WORKING PAPER \#9

MAY 1979

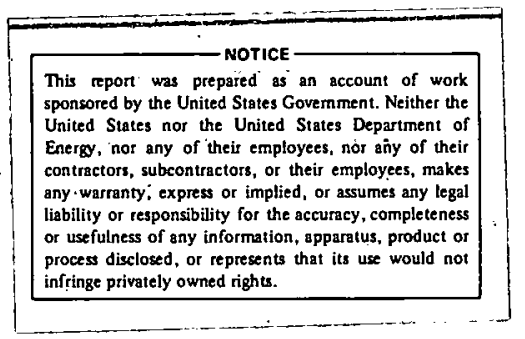

This report was prepared as an account of work ponsored by the United States Government. Neither the Energy, nor any of their amployces, nor any of their contractors, subcontretors, or their employees, makes 


\section{DISCLAIMER}

This report was prepared as an account of work sponsored by an agency of the United States Government. Neither the United States Government nor any agency Thereof, nor any of their employees, makes any warranty, express or implied, or assumes any legal liability or responsibility for the accuracy, completeness, or usefulness of any information, apparatus, product, or process disclosed, or represents that its use would not infringe privately owned rights. Reference herein to any specific commercial product, process, or service by trade name, trademark, manufacturer, or otherwise does not necessarily constitute or imply its endorsement, recommendation, or favoring by the United States Government or any agency thereof. The views and opinions of authors expressed herein do not necessarily state or reflect those of the United States Government or any agency thereof. 


\section{DISCLAIMER}

Portions of this document may be illegible in electronic image products. Images are produced from the best available original document. 
INTRODUCTION

This project was undertaken primarily to show how one might use SPSS(Statistical Package for the Social Sciences) to analyze air pollution data. As an example, this paper looks specifically at the ozone concentration correlation coefficients between the 25 BAAYCD's (Bay Area Air Follution Control Districts) for the months of July, August and September 1978. 
DATA

A file named $\langle S$. SWITZER〉AIRFOL.DAT on the Low Overhead Time Sharing(LOTS) system at Stanford University contains daily air pollution data for July 1, 1978 through september 30, 1978. The data is formatted to be used with the following SFSS(Statistical

Package for the Social Sciences)commands:

VARIABLE LIS'T DOW, YEAR, MONTH, DAY, CMWS, VAMWS, SJMWS, CTEMF, VATEMP, SJTEMP, SF INSO, SRINSO, SJ INSO, OAS'TAB, VASTAB, SJSTAB, SFO, SRO, RIO, FTO, CCO, WCO, OAO, SLO, HAO, FRO, LIO, ARO, SJC, GIO, LGO, SAO, MVO, RCO, BUO, FEO, STO, SOO, NFO, VAO, FFC, SFY, FOF, SRF, RIF, PIP, CCP, FRP, I.IP, SJP, GIP, SAF, RCP, INPUT FORMAT BUP, STP, NPF, VAF, FARCOD INPUT MEDIUM FIXED (1X,I1,3I2,3\%4.1,9I3,2.5I2,16I3, I1) $\mathrm{N}$ GF CASES $\quad 92$

The definitions along with the code or units of the variables are presented in Table 1.

When there was a missing data point for ozone concentration, the following technique was used to estimate a data point to be placed in the data file:

(1) Compute $M$, the monthly mean of the ozone concentration using only the original data for the given station.

(2) Compute $D$, the daily mean of the ozone concentration using only the stations with original data.

(3) Compute $A$, the mean using all the original data used in (1) and (2).

(4) Compute the estimated data point, $X=M+D-A$. When PARCOD $=2$, the data points for the particulate concentration at all stations are equal to 999 . When FARCOD $=1$, the missing data points were estimated with the same technique used for ozone concentration. 
SFSS

Varlable

Name.

Definition

Code or Units

DOW Day of week

1 = Sunday

2 = Monday

3 = Tuesday

$4=$ Wednesday

5 = Thursday

$6=$ Friday

7 = Saturday

YEAR Year

$78=1978$

MONTH Month

$7=\mathrm{July}$

$8=$ August

$9=$ September

DAY Day of month

$1=1, \ldots .31=3$

CMWS Mean wind speed for Central averaged from

miles/hour

San Francisco and Cakland Airports

VAMWS Mean wind speed for North from

$\mathrm{miles} / \mathrm{hour}$

BAAFCD Vallejo: station

SJWMS Mean wind speed for South from

miles/hour

BAAFCD San Jose station

CTEMP. Mean maximum temperature for Central averaged ${ }^{\circ} \mathrm{F}$

from San Francisco, San Francisco Airport and Oakland Airport

VATEMP Mean maximum temperature for North from Vallejo

SJTEMP Mean maximum temperature for south from San Jose

SFINSO Insolation from San Francisco

Langleys/day

SRINSO Insolation from San Rafael

Langleys/day

SJINSO Insolation from San Jose

Langleys/day

OASTAB Temperature at 2500 feet above Oakland

minus that at the surface

VASTAB Temperature at 2500 feet above Vallejo. minus that at the surface

SJSTAB Temperature at 2500 feet above San Jose minus that at the surface
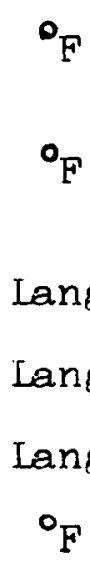

$F$

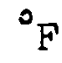

${ }^{\circ} \mathrm{F}$ 
Variable.

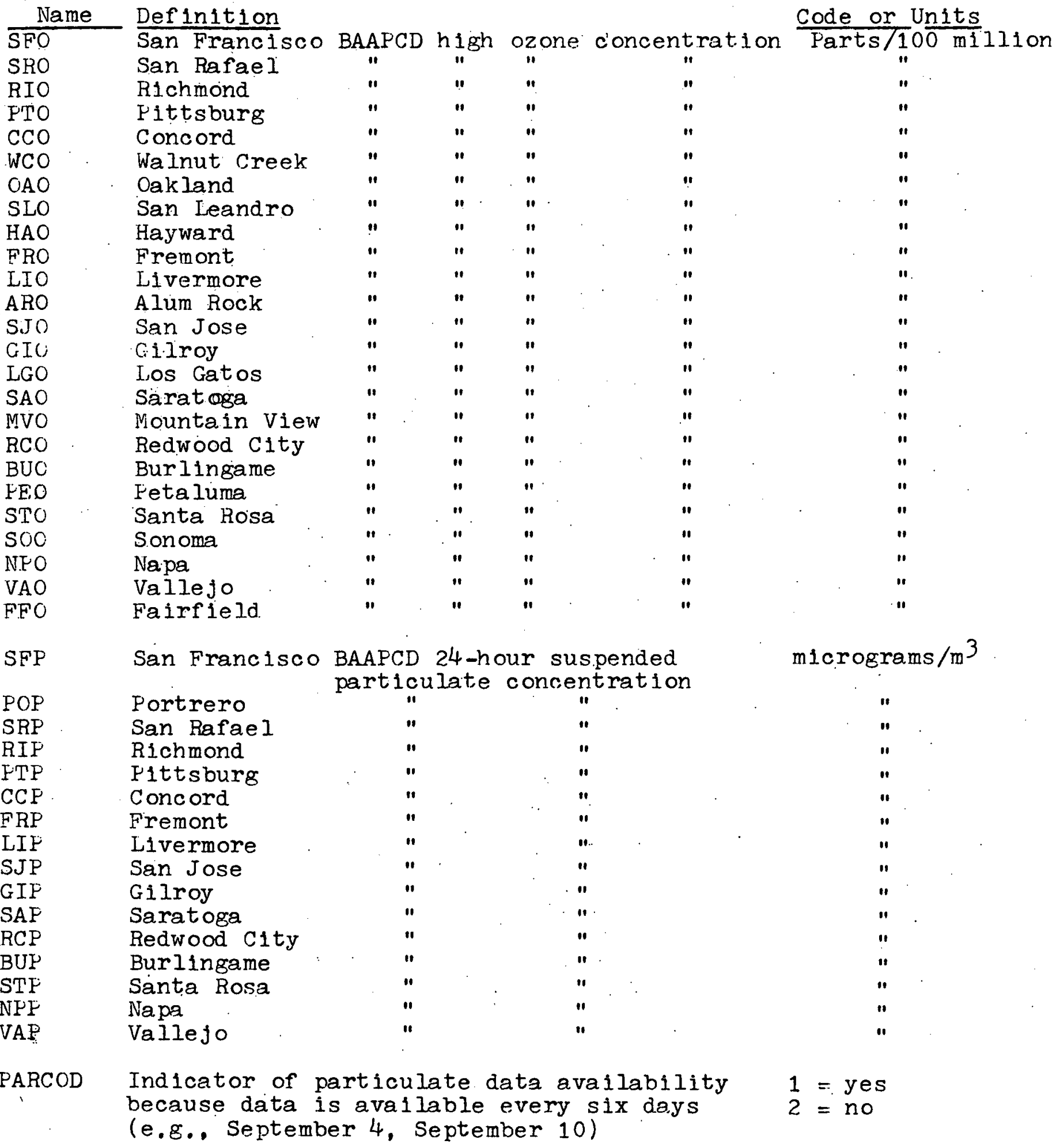




\section{CORRELATIONS}

The following commands were used to find the ozore concentration correlation coefficients between the 25 Bay Area Air Follution Control Districts. (BAAPCD's) during the month of July 1978:

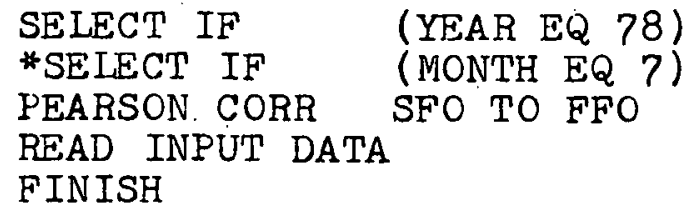

Of the 300 correlation coefficients, the twenty with the highest values are between:

$\begin{array}{lc}\text { Sonoma, Napa } & 0.9461 \\ \text { Hayward, Fremont } & 0.9341 \\ \text { Alum Rock, Saratoga } & 0.9256 \\ \text { Petaluma, Sonoma } & 0.9225 \\ \text { Alum Rock, Los Gatos } & 0.9207 \\ \text { Hayward, Saratoga } & 0.9199 \\ \text { Hayward, Sonoma } & 0.9197 \\ \text { Concord, Livermore } & 0.9167 \\ \text { Alum Rock, San Jose . } & 0.9151 \\ \text { Hayward, Alum Rock } & 0.9097 \\ & \\ \text { Saratoga, Napa } & 0.9080 \\ \text { Hayward, Napa } & 0.9078 \\ \text { Pittsburg, Sonoma } & 0.9074 \\ \text { Saratoga, Sonoma } & 0.9060 \\ \text { Concord, Napa } & 0.9059 \\ \text { Hayward, Redwood City } & 0.9054 \\ \text { San Leandro, Valle jo } & 0.9049 \\ \text { Saratoga, Redwood City } & 0.9024 \\ \text { Fittsburg, Napa } & 0.8995 \\ \text { Pittsburg, Concord } & 0.8993\end{array}$

In Figure 1, solid lines are used to connect the cities with the ten higheșt correlation coefficients. Broken lines are used to connect the cities with the next ten highest correlation coefficients. Using (MONTH EQ 8) instead of (MONTH EQ 7) in the above sequence of commands, the 300 ozone correlation coefficients for the month of August 1978 were computed. The 20 coefficients with the largest values are: 


$\begin{array}{ll}\text { Saratoga, Mountain View } & 0.9567 \\ \text { Concord, Walnut Creek } & 0.9380 \\ \text { Fremont, Alum Rock } & 0.9325 \\ \text { Fremont, Mountain View } & 0.9275 \\ \text { Los Gatos, Saratoga } & 0.9267 \\ \text { San Jose, Los Gatos } & 0.9176 \\ \text { Walnut Creek, Fairfield } & 0.9100 \\ \text { Los Gatos, Mountain View } & 0.9037 \\ \text { Alum Rock, Mountain View } & 0.9020 \\ \text { Littsburg, Fairfield } & 0.8983 \\ \text { Livermore, Fairfield } & 0.8976 \\ \text { Walnut Creek, Livermore } & 0.8909 \\ \text { Concord, Mountain View, } & 0.8907 \\ \text { Napa, Fairfield } & 0.8889 \\ \text { Mountain View, Fairfield } & 0.8855 \\ \text { Livermore, Mountain View } & 0.8796 \\ \text { San Jose, Mountain View } & 0.8761 \\ \text { Concord, Fairfield } & 0.8697 \\ \text { Fremont, Saratoga } & 0.8693 \\ \text { Alum Rock, Fairfield } & 0.8667\end{array}$

In Figure 2, solid lines are used to connect the cities with the ten highest correlation coefficients. Broken lines are used to connect the cities with the next ten highest correlation coefficients. Lastly, (MONTH EQ 9) was used to obtain the correlation coefficients for September 1978. The highest twenty are:

$\begin{array}{ll}\text { Concord, Walnut Creek } & 0.9812 \\ \text { Alum Rock, San Jose } & 0.9676 \\ \text { San Leandro, Hayward } & 0.9664 \\ \text { Pittsburg, Walnut Creek } & 0.9615 \\ \text { Plttsbarg, Concord } & 0.9602 \\ \text { Saratoga, Mountain View } & 0.9597 \\ \text { San Jose, Mountain View } & 0.9574 \\ \text { Hayward. Fresno } & 0.9521 \\ \text { Hayward, Alum Rock } & 0.9493 \\ \text { Los Gatos, Sratoga } & 0.9485\end{array}$

$\begin{array}{ll}\text { Alum Rock, Saratoga } & 0.9473 \\ \text { Richmond, Oakland } & 0.9471 \\ \text { San Jose, Saratoga } & 0.9468 \\ \text { San Rafae 1, Sonoma } & 0.9463 \\ \text { Sonoma, Napa } & 0.9425 \\ \text { Richmond, Santa Rosa } & 0.9416 \\ \text { Hayward, San Jose } & 0.9387 \\ \text { Oakland, Santa Rosa } & 0.9380 \\ \text { Fremont, Alum Rock } & 0.9371 \\ \text { Hayward, Los Catos } & 0.9354\end{array}$


As with the correlation coefficients for July and August, the september coefficient relationships are indicated on a map. In Figure 3, solid Iines are used to connect the cities with the ten highest correlation coefficients and broken lines are used to connect the cities with the next ten highest correlation coefficients for ozone concentration.

Before trying to determine if there is any significance to the patterns in the maps of Figures 1,2 and 3 , the following additional correlation coefficients were computed for the combined months of July, August and september 1978:

$r$ between SJO and SJMWS $=-0.4412$

$r$ between SJO and SJTEMP $=+0.8227$

$r$ between SJO and SJSTAB $=+0.6614$

$r$ between SJO and SJINSO $=+0.0959$

$r$ between VAO and VAMWS $=-0.8355$

$r$ between VAO and VATEMP $=+0.5723$

$r$ between $\mathrm{VAO}$ and $\mathrm{VASTAB}=+0.5138$

The two coefficients with the greatest magnitudes involve the mean wind speed and the mean maximum temperature. Therefore, these two weather factors will be considered in any explanations of Figures 1, 2 and 3 . 
In Figure 1, there seems to be a band of stations surrounding San Francisco Bay, where the ozone concentrations are highly correlated. This band consists of Petaluma, Sonoma, Napa, Pittsburg, Concord, Livermore, Hayward, Fremont, Alum Rock, San Jose, Los Gatos, Saratoga, and Redwood City. Santa Rosa and Fairfield fall outside this band while the other stations fall inside the band.

In Figure 2, there seems to be a similar band consisting of Napa, Fairfield, Pittsburg, Concord, Walnut Creek, Livermore, Fremont, Alum Rock, San Jose, Los Gatos, Saratoga, and Mountain View. All of the other stations fall inside the band.

In Figure 3, the zone of high correlation consists of only San Leandro, Hayward, Fremont, Alum Rock, San Jose, Los Gatos, Saratoga, and Mountain View. 


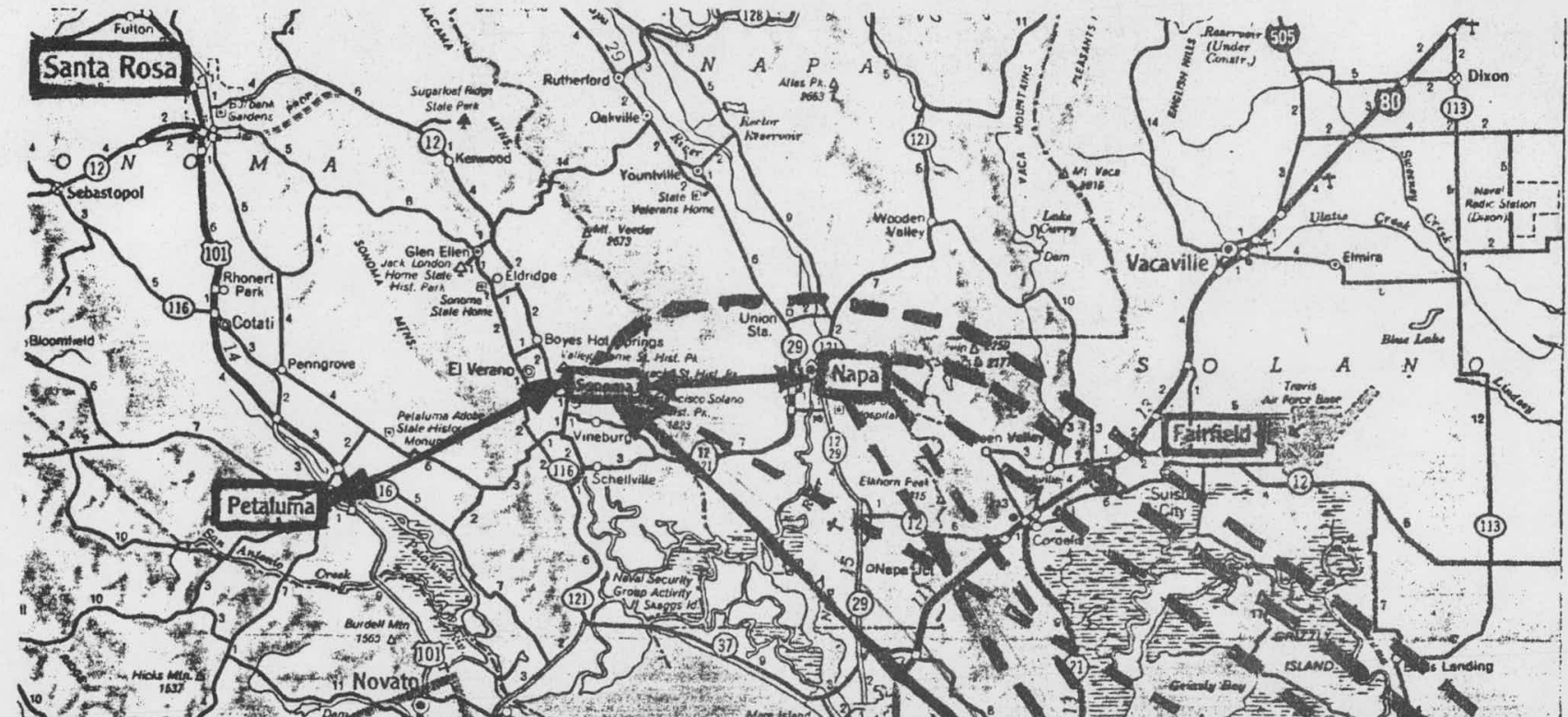

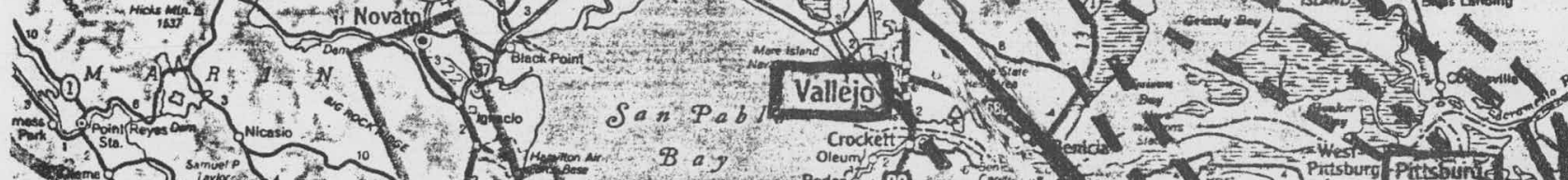

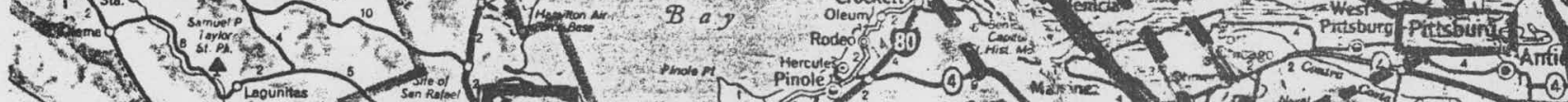
$-12-12-2 x+1-2$

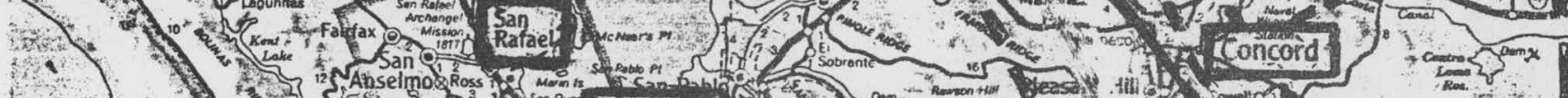

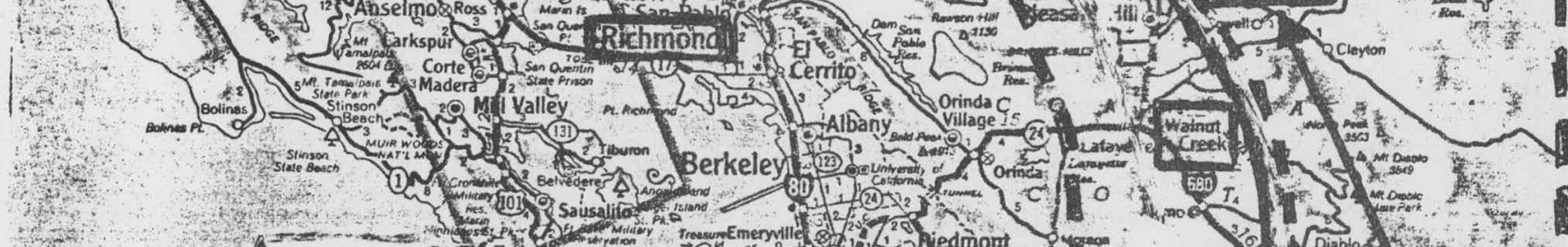

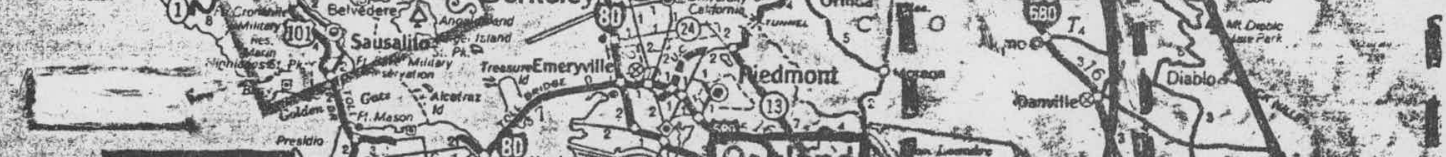

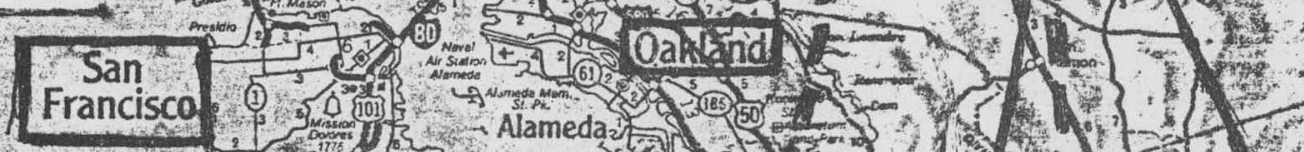

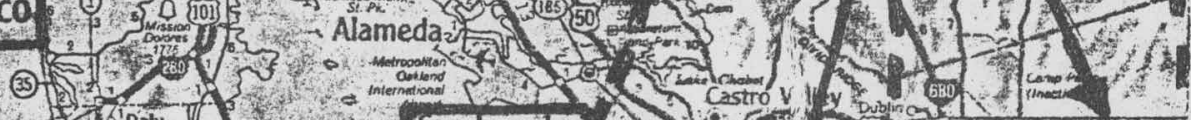

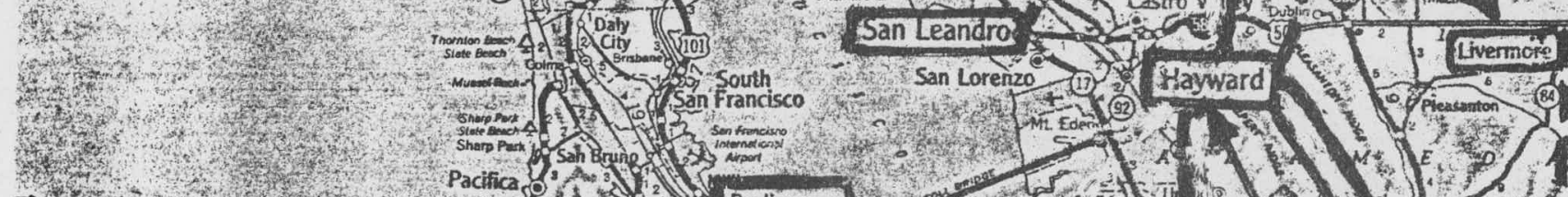

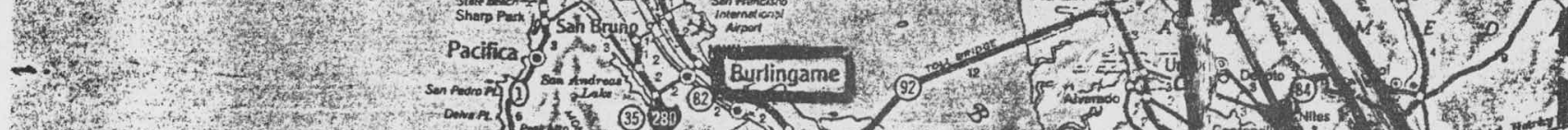

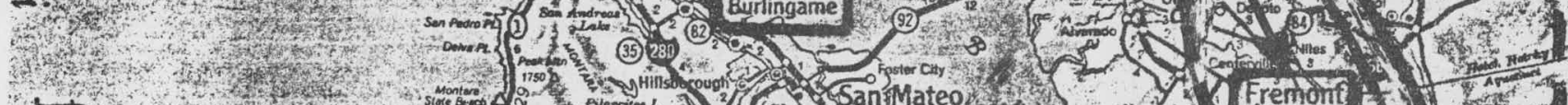
S.

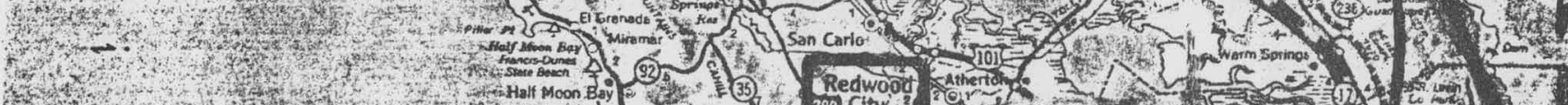

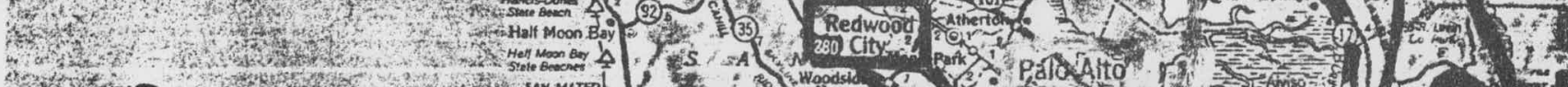

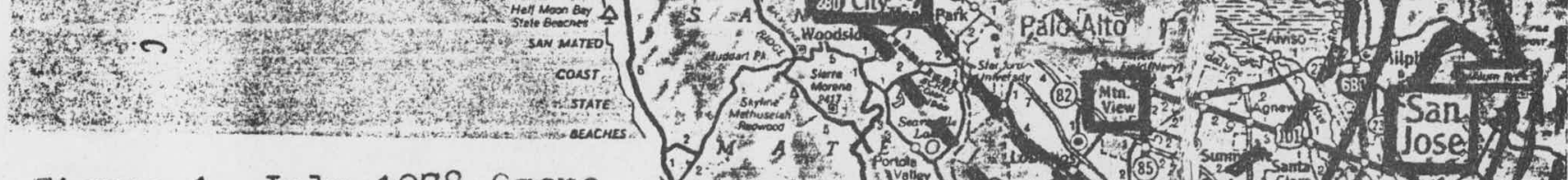

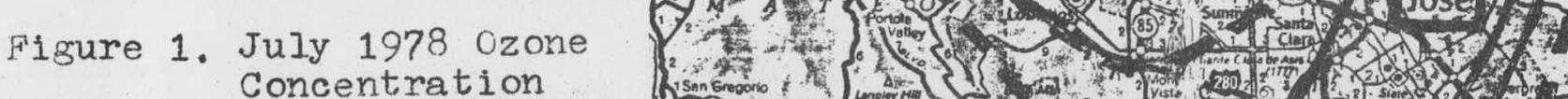
Relationships

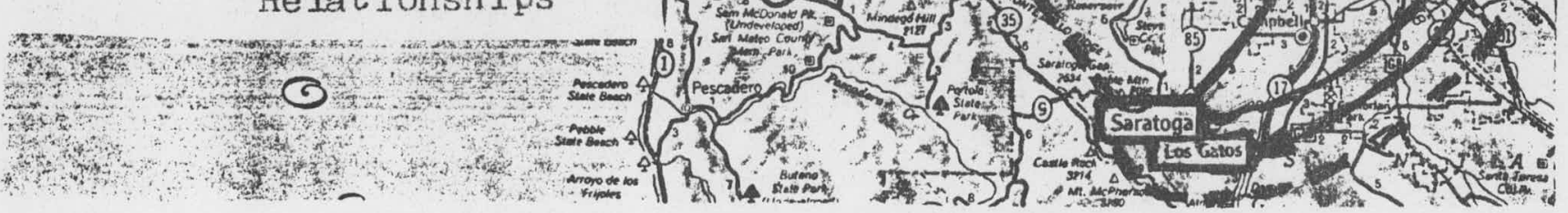




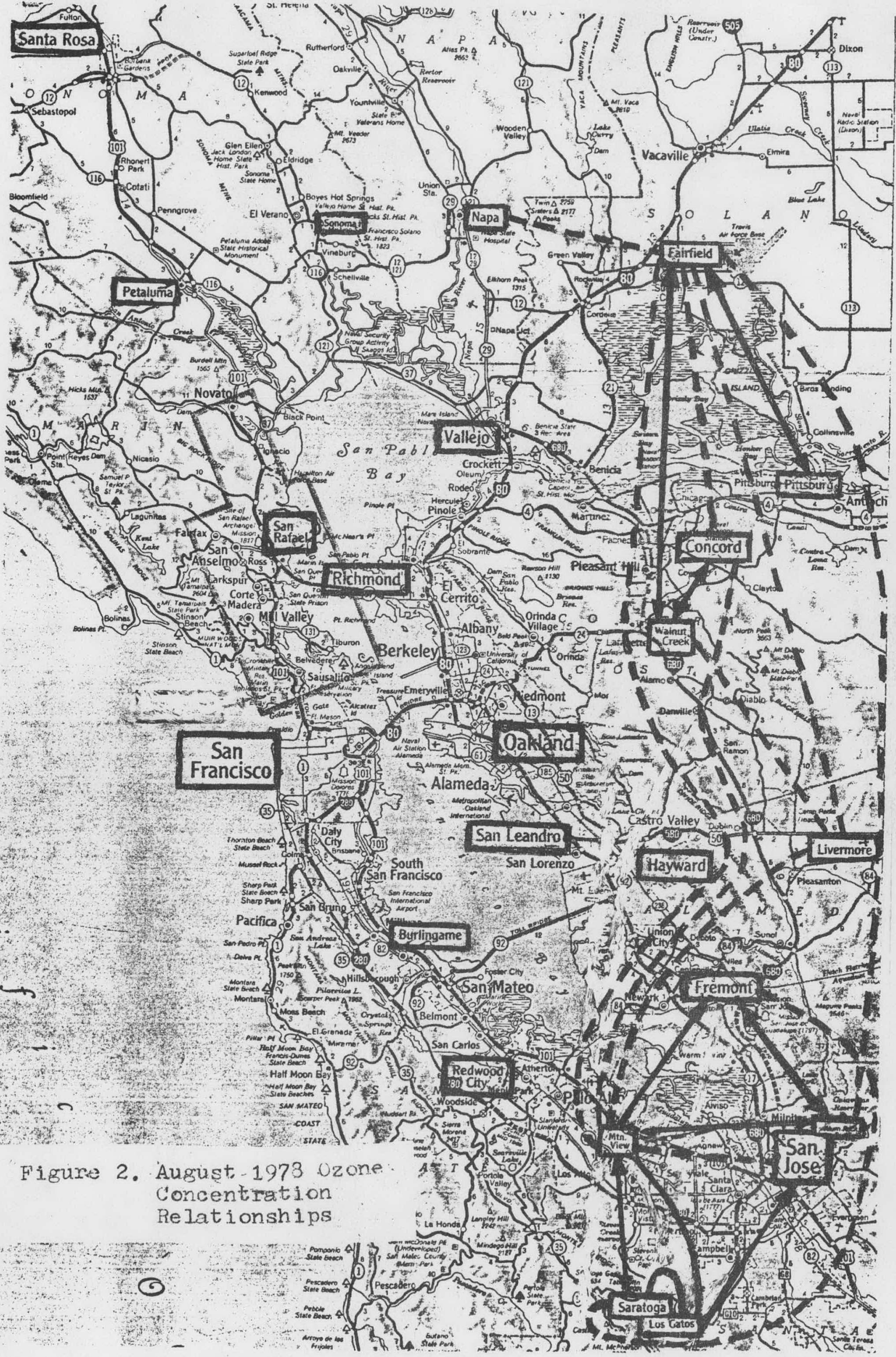




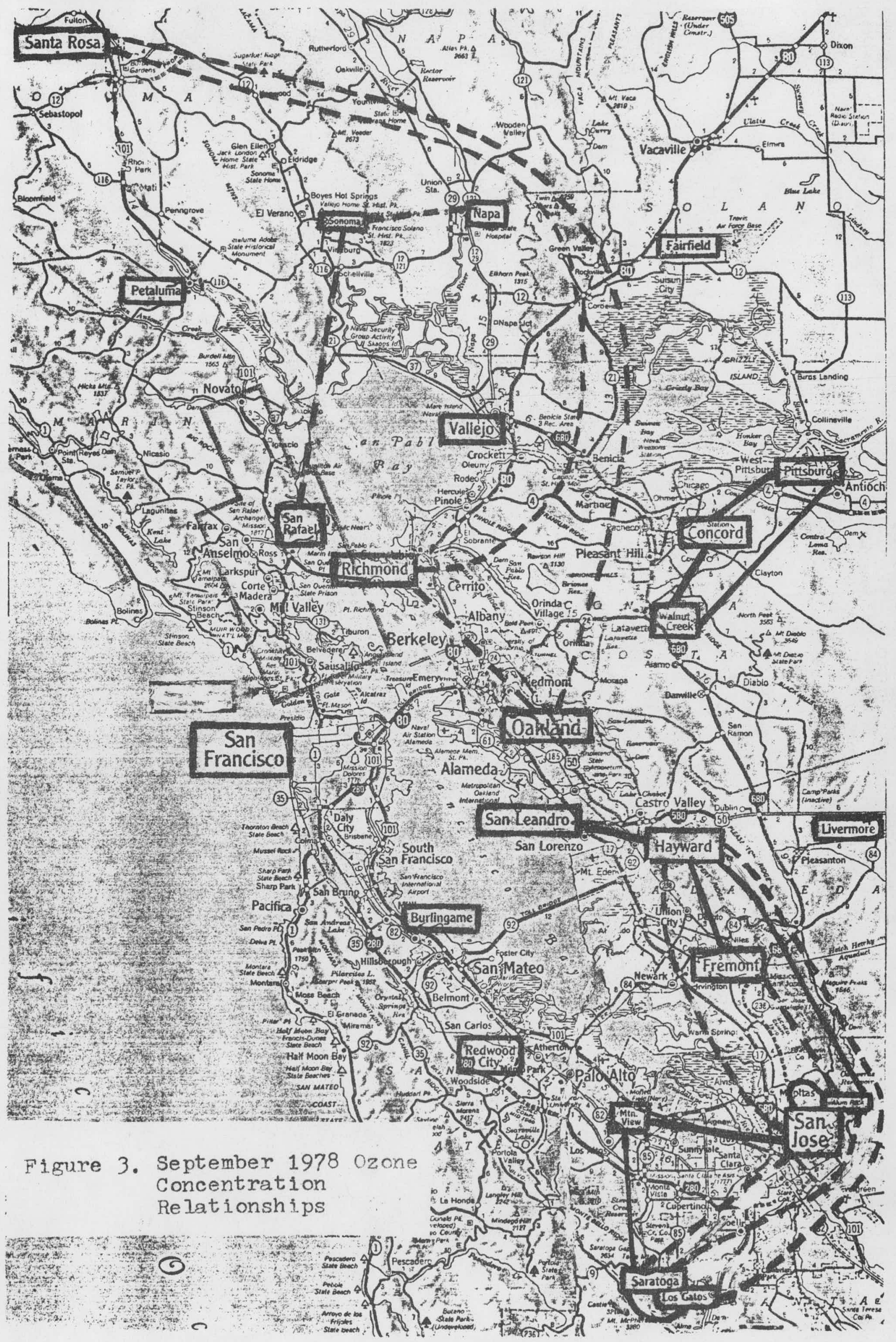

